\title{
PENINGKATAN KETERAMPILAN MENULIS TEKS BIOGRAFI MELAUI MODEL THINK TALK WRITE PADA PESERTA DIDIK KELAS X IPA 2 SMA N og MALANG
}

\author{
SANTIKA DAMAYANTI SARI', ANIK SRI UTAMI', HARI SUNARYO3 \\ Universitas Muhammadiyah Malang \\ sarisantica@yahoo.co.id', aniksutami@gmail.com², harinaryo@yahoo.co.id ${ }^{3}$
}

Pertama Diterima: 31 Maret 2019

Bukti Akhir Diterima: 6 Juni 2019

\begin{abstract}
Abstrak
Tujuan penelitian ini adalah untuk mendeskripsikan proses pembelajaran menulis biografi melalui model think talk write pada peserta didikkelas X IPA 2, mendeskripsikan peningkatan keterampilan menulis biografi peserta didiksetelah mengikuti pembelajaran ini, dan mendeskripsikan perubahan perilaku peserta didikkelas X IPA SMA Negeri 9 Malang selama mengikuti pembelajaran menulis biografi menggunakan model think talk write. Metode penelitian yang digunakan yaitu Penelitian Tindakan Kelas (PTK) yang terdiri atas dua siklus yaitu siklus I dan siklus II. Siklus I terdiri atas perencanaan, tindakan, observasi, dan refleksi. Siklus II juga terdiri atas perencanaan, tindakan, observasi, dan refleksi. Hasil penelitian menunjukkan adanya peningkatan proses pembelajaran menulis biografi, menunjukkan adanya perubahan perilaku pada peserta didik, serta adanya peningkatan keterampilan menulis biografi. Siklus I nilai rata-rata kelas sebesar 79,7 dan siklus II sebesar 88,9. Hal ini menunjukkan peningkatan dari siklus I hingga siklus II sebesar 9,2.
\end{abstract}

Kata kunci: peningkatan,menulisbiografi, model think talk write

\begin{abstract}
The purpose of this study was to describe the learning process of writing biography through the think talk write model on students of class XIPA 2, describing the improvement of students' biographical writing skills after attending this study, and describing the behavior changes of class X students of SMA Negeri 9 Malang while participating learning to write biography using the think talk write model. The research method used is Classroom Action Research which consists of two cycles, namely cycle I and cycle II. Cycle I consists of planning, action, observation, and reflection. Cycle II also consists of planning, action, observation, and reflection. The results showed an increase in the learning process of writing biographies, showing a change in behavior among students, and an increase in biography writing skills. The first cycle of the class average value was 79.7 and the second cycle was 88.9. This shows an increase from the first cycle to the second cycle of 9.2 .
\end{abstract}

Keywords: improvement, writing biography, think talk write models

\section{PENDAHULUAN}

Pada prinsipnya tujuan pembelajaran bahasa Indonesia bagi para peserta didik adalah untuk menguasai keterampilan berbahasa yang meliputi empat aspek keterampilan berbahasa, yaitu:(1)keterampilan menyimak; (2)keterampilan berbicara; (3) keterampilan membaca;dan (4) keterampilan menulis.Keempat keterampilan berbahasa ini memiliki hubungan yang sangat erat, karena salah satu dari keterampilan ini tidak bisa berdiri sendiri tanpa ditunjang oleh keterampilan lainnya. Aspek menyimak dan membaca merupakan keterampilan berbahasa yang bersifat reseptif 
atau menerima, sedangkan aspek berbicara dan menulis keterampilan berbahasa yang bersifat produktif atau menggunakan. Setiap keterampilan berbahasa erat pula hubungannya dengan proses yang mendasari bahasa. Keterampilan berbahasa hanya dapat diperoleh dan dikuasai dengan jalan praktik dan banyak berlatih. Melatih keterampilan berbahasa berarti melatih keterampilan berpikir.

Keterampilan menulis sebagai salah satu keterampilan berbahasa yang bersifat produktif sangat penting bagi peserta didik. Dalam menulis peserta didik diharapkan dapat mengungkapkan ide, gagasan, pengalaman, dan pendapat dalam berbagai tulisan. Untuk sampai pada keterampilan tersebut, diperlukan banyak latihan menulis dalam kehidupan sehari-hari. Dengan menulis, peserta didik mampu mengkonstruki berbagai ilmu atau pengetahuan yang dimilikinya dalam sebuah tulisan, baik dalam bentuk esai, artikel, laporan ilmiah, berita,cerpen, puisi dan sebagainya.

Menurut Rosidi (2009:3) menulis adalah salah satu bentuk berpikir, yang juga merupakan alat untuk membuat orang lain atau pembaca berpikir. Dengan menulis, peserta didikmampu mengkonstruki berbagai ilmu atau pengetahuan yang dimilikinya dalam sebuah tulisan, baik dalam bentuk esai, artikel, laporan ilmiah, berita, cerpen, puisi dan sebagainya. Tujuan pengajaran menulis di sekolah adalah agar peserta didikmempunyai kemampuan menulis sehingga peserta didiktidak beranggapan bahwa keterampilan menulis itu merupakan kegiatan yang rumit. Di samping itu, tujuan yang diharapkan dalam pembelajaran menulis di sekolah adalah agar peserta didikmampu memahami dan dapat mengungkapkan apa yang mereka tangkap, gagasan, pendapat, pesan dan perasaan dalam bentuk tertulis.

Tarigan (2008:3) mengemukakan bahwa menulis merupakan suatu kegiatan yang produktif dan ekspresif. Dalam kegiatan menulis, penulis haruslah terampil memanfaatkan grafologi, struktur bahasa, dan kosa kata. Keterampilan menulis ini tidak akan datang secara otomatis, tetapi harus melalui latihan dan praktik yang banyak dan teratur. Menurut Proett dan Gill dalam Suparno dan Yunus (2008) sebagai proses, menulis merupakan serangkaian aktivitas yang terjadi dan melibatkan beberapa fase yaitu fase prapenulisan, penulisan dan pascapenulisan. Fase prapenulisan adalah fase mencari, menemukan dan mengingat kembali pengetahuan atau pengalaman yang diperoleh dan diperlukan penulis. Fase penulisan adalah siap untuk menulis mengembangkan butir demi butir ide yaang terdapat dalam kerangka karangan, dengan memanfaatkan bahan atau informasi yang telah dipilih dan dikumpulkan. Fase pascapenulisan Fase ini merupakan tahap penghalusan dan penyempurnaan buram yang dihasilkan.Menulis biasanya digunakan untuk membuat sebuah karangan baik fiksi maupun nonfiksi. Karangan fiksi dapat berupa prosa, novel, dan naskah drama. Karangan nonfiksi dapat berupa biografi, argumentasi, persuasi, eksposisi, deskripsi, pengalaman pribadi, dan otobiografi. Oleh karena itu, penulis memilih menulis biografi sebagai salah satu upaya meningkatkan kemampuan peserta didik.

Pada kurikulum 2013 menulis biografi merupakan bagian dari salah satu kompetensi dasar (KD) yang harus dicapai oleh peserta didik kelas X SMA. Kompetensi dasar (KD) yang harus dicapai adalah menyusun teks biografi.Pencapaian tujuan sesuai dengan kurikulum 2013 pada proses pembelajaran bahasa Indonesia yang berbasis teks bukan sekadar ditekankan pada teori saja, tetapi peserta didikjuga melakukan praktik langsung terutama dalam mengungkapkan, menuangkan, dan mengembangkan ide atau gagasannya ke dalam susunan sebuah karya tulis. 
Teks biografi merupakan suatu karya tulis yang mengisahkan seorang tokoh, peristiwa dan masalah yang dialami tokoh, yang ditulis oleh orang lain. Melalui kegiatan menulis teks biografi, peserta didikdapat mendokumentasikan suatu kisah hidup seorang tokoh dalam bentuk tulisan, dan hasil tulisan dapat memberikan suatu informasi kepada pembaca mengenai perjalanan hidup seseorang.

Sukirno (2016:55) menyatakan bahwa biografi adalah tulisan yang isinya menceritakan atau mengisahkan kehidupan seseorang atau orang lain. Dalam tulisan tersebut juga berisi biodata, dan riwayat hidup tokoh yang ditulis. Sependapat dengan hal tersebut, Harahap (2014:6) menyatakan bahwa biografi, yaitu penelitian terhadap seorang tokoh dalam hubungannya dengan masyarakat; sifat-sifat, watak, pengaruh pemikiran dan idenya, dan pembentuk watak tokoh tersebut selama hayatnya. Dalam dunia pendidikan, biografi dipelajari peserta didikagar dapat mengikuti keteladanan seorang tokoh. Melalui biografi, seorang peserta didikdiharapkan terinspirasi oleh rangkaian kisah tokoh sehingga dapat membentuk karakter yang cerdas dan berakhlak mulia sesuai dengan tujuan pendidikan, terutama yang terdapat dalam kurikulum 2013 membuahkan keberhasilan.

Tujuan dalam menulis biografi yaitu peserta didik mampu memahami unsur dan ciri kebahasaan dalam teks biografi, serta peserta didik mampu menulis biografi dengan memerhatikan struktur dan penggunaan bahasa sesuai dengan PUEBI. Melalui menulis penulis berharap agar peserta didiklebih menuangkan kemampuan yang ada dalam dirinya. Pada pembelajaran menulis teks biografi peserta didik diharapkan mampu menggambarkan tokoh sesusai dengan unsur, struktur dan ciri kebahasaan teks biografi.

Keterampilan menulis teks biografi peserta didik kelas X IPA 2 SMA Negeri 9 Malang sebagai salah satu dari empat keterampilan bahasa masih rendah. Hal ini didapat dari data wawancara oleh peneliti dengan guru mata pelajaran Bahasa Indonesia di SMA Negeri 9 Malang. Data tersebut mengungkap nilai rata-rata yang diperoleh peserta didik dalam penulisan teks biografi hanya sebesar 73,4 hanya 12 orang saja yang mampu memenuhi nilai KKM dengan nilai $\geq 78$. Rendahnya keterampilan peserta didik dalam menulis teks biografi disebabkan oleh faktor internal peserta didik yang menganggap sulit pembelajaran menulis teks biografi, terutama dalam hal memunculkan ide dan pembentukan struktur kalimat. Beberapa faktor penghambat yang dialami peserta didik kelas $\mathrm{X}$ IPA 2 dalam kemampuan menulis di SMA Negeri 9 Malang yaitu (1) peserta didik kurang latihan dalam menulis, (2) peserta didik mengalami kebingungan untuk hal menyusun kalimat dan memunculkan ide, (3) kurangnya penguasaan keterampilan berbahasa, seperti penggunaan tanda baca, kaidah-kaidah penulisan (4) metode dan media yang digunakan kurang menarik perhatian peserta didik, (5) model pembelajaran yang digunakan kurang sesuai.

Kegiatan menulis memerlukan sejumlah potensi pendukung yang untuk mencapainya diperlukan kesungguhan, kemauan keras, dan harus belajar dan berlatih dengan sungguh-sungguh dan terus-menerus dalam waktu yang cukup lama. Melihat kenyataan tersebut, pembelajaran bahasa Indonesia khususnya pembelajaran menulis, perlu upaya yang tepat untuk meningkatkan nilai menulis peserta didik. Penggunaan model pembelajaran yang lebih menarik akan menjadikan salah satu upaya dalam meningkatkan kemampuan peserta didik dalam menulis biografi. 
Model pembelajaran adalah bentuk pembelajaran yang menggambarkan kegiatan awal hingga akhir yang disajikan khas oleh guru. Penggunaan model pembelajaran bukan hanya terfokus pada guru sebagai pengajar, akan tetapi lebih melibatkan aktivitas peserta didik sebagai pembelajar. Sehingga akan terjadi sebuah sinkronisasi antara guru dan peserta didik.

Inovasi pembelajaran dapat diketahui dengan menggunakan model pembelajaran. Menurut Winataputra dalam Kusmaryono et al (2016:80) model pembelajaran adalah kerangka konseptual yang melukiskan prosedur yang sistematis dalam mengorganisasikan pengalaman belajar untuk mencapai tujuan belajar tertentu, berfungsi sebagai pedoman bagi para perancang pembelajaran dan para pengajar dalam aktivitas pembelajaran. Dalam penggunaan model pembelajaran diharapkan dapat mengatasi permasalahan yang ada.

Ada berbagai pilihan model pembelajaran, salah satunya adalah model think talk write. Penerapan think talk write dalam pembelajaran kooperatif dapat mendorong peserta didik untuk berfikir, aktif berpartisipasi dalam diskusi kelompok, berkomunikasi dengan baik, siap mengemukakan pendapatnya, menghargai orang lain dan melatih peserta didik untuk menuliskan hasil diskusinya ke dalam bentuk tulisan secara sistematis. Model pembelajaran think talk writemerupakan salah satu model pembelajaran kooperatif. Model think talk write merupakan suatu model yang mengutamakan adanya kerjasama, yakni kerjasama antarpeserta didik dalam kelompok untuk mencapai tujuan pembelajaran. Dalam pembelajaran think talk writepeserta didik dituntut untuk mengeluarkan ide yang dimilikinya untuk kemudian membaginya dengan teman sekelompok untuk saling mendapat masukan dan motivasi.

Model pembelajaran think talk write tidak sama dengan sekadar belajar dalam kelompok. Ada unsur-unsur dasar pembelajaran model think talk write yang membedakan dengan pembagian kelompok yang dilakukan asal-asalan. Aktivitas berpikir atau think yang dapat dilihat dari proses mencari informasi dari tokoh kemudian membuat catatan kecil mengenai apa yang telah dilihatnya. Menurut Wiedehold dalam Ansari (2003:36) membuat catatan berarti menganalisis tujuan isi teks dan memeriksa bahan-bahan yang ditulis. Selain itu, belajar rutin membuat/menulis catatan setelah membaca, dapat merangsang aktivitas berpikir sebelum, selama, dan setelah membaca. Membuat catatan dapat mempertinggi pengetahuan peserta didik, bahkan meningkatkan keterampilan berpikir dan menulis.

Tahap kedua setelah think adalah talk yaitu berkomunikasi dengan menggunakan kata-kata dan bahasa yang mereka pahami. Talking juga dapat membantu guru untuk mengetahui pemahaman peserta didik dalam belajar, sehingga dapat mempersiapkan perlengkapan pembelajaran yang dibutuhkan. Komunikasi model think talk write memungkinkan peserta didik untuk terampil berbicara. Proses komunikasi dapat dibangun di kelas secara alami dan mudah serta dapat dimanfaatkan sebagai alat menulis. komunikasi dalam suatu diskusi dapat membantu kolaborasi dan meningkatkan pemahaman.

Tahap ketiga dalam model think talk write adalah write yaitu menuliskan hasil diskusi secara individual. Aktivitas menulis berarti mengkonstruksikan ide, karena setelah berdiskusi atau berdialog antarteman, kemudian peserta didik mengungkapkannya ke dalam bentuk tulisan.

Pelaksanaan prosedur model think talk write dengan benar akan memungkinkan pendidik mengelola kelas dengan lebih efektif. Ada berbagai elemen yang merupakan ketentuan pokok 
dalam pembelajaran model think talk write, yaitu a) mengamati dengan seksama, b) menggali ide yang dimiliki, c) saling berbagi secara positif (positive sharing), d) interaksi tatap muka (face to face interaction), e) keterampilan mengembangkan ide yang dimiliki, dan f) keterampilan untuk menjalin hubungan antarpribadi atau keterampilan sosial. Model pembelajaran ini lebih menekankan keterlibatan peserta didik secara penuh. Peserta didik dituntut untuk bisa aktif dan produktif serta terampil dalam hal menulis.

Beberapa hasil penelitian terdahulu yang relevan dengan topik penelitian ini yaitu penelitian tentang peningkatan menulis dan menggunakan model think talk write adalah Anisah (2010) dalam penelitiannya yang berjudul "Peningkatan Keterampilan Menulis Karangan Narasi dengan mengubah teks wawancara melalui Model Think Talk Write pada Siswa Kelas VII A SMP Negeri 2 Cepiring", menunjukkan adanya peningkatan rata-rata keterampilan menulis sebesar 17,1 atau 28,1\% dari prasiklus ke siklus II. Angka peningkatan tersebut diperoleh dari rata-rata keberhasilan prasiklus 60,7 siklus I sebesar 70 sementara pada siklus II meningkat menjadi 14,24\%.

Berdasarkan latar belakang yang diuraikan di atas, maka penerapan model think talk write dalam menulis teks biografi ini diduga dapat dijadikan sebagai alternatif untuk mencapai salah satu tujuan pembelajaran mata pelajaran bahasa Indonesia di SMA. Untuk itulah, peneliti akan melakukan penelitian tentang menulis biografi pada peserta didik kelas X IPA 2 SMA Negeri 9 Malang dengan judul "Peningkatan Keterampilan Menulis Biografi melalui Model Think Talk Write pada Peserta Didik Kelas X IPA 2 SMA Negeri 9 Malang."

Berdasarkan latar belakang yang telah dijelaskan diatas, maka rumusan masalah yang akan dikaji dalam penelitian ini adalah sebagai berikut: (1) Bagaimana peningkatan kualitas proses pembelajaran keterampilan menulis biografi melalui model think talk write; (2) Bagaimana peningkatan keterampilan menulis teks biografi untuk peserta didik kelas X IPA 2 SMA Negeri 9 Malang setelah mengikuti pembelajaran menulis biografi melalui model think talk write; dan (3) Bagaimana perubahan perilaku peserta didik kelas X IPA 2 SMA Negeri 9 Malang dalam menulis biogarfi setelah mengikuti pembelajaran menulis biografi melalui model think talk write.

\section{METODE PENELITIAN}

Jenis penelitian tentang peningkatan keterampilan menulis biografi melalui model think talk write pada peserta didik kelas X IPA 2 SMA Negeri 9 Malang adalah Penelitian Tindakan Kelas (PTK). Arikunto et al (2008:2) menjelaskan bahwa penelitian tindakan kelas adalah suatu kegiatan mencermati suatu objek dengan menggunakan cara dan aturan metodologi tertentu untuk memperoleh data atau informasi yang bermanfaat dalam meningkatkan mutu suatu hal yang menarik minat dan penting bagi peneliti. Penelitian tindakan kelas terdiri atas siklus, yaitu proses tindakan pada siklus. Tiap siklus terdiri dari empat komponen, yaitu perencanaan, tindakan, observasi, dan refleksi.

Penelitian ini menggunakan desain penelitian tindakan kelas (PTK) dengan dua siklus, yaitu proses tindakan pada siklus I dan siklus II. Pada siklus I bertujuan untuk mengetahui keterampilan peserta didik dalam menulis biografi. Sedangkan hasil penelitian proses diadakan pada siklus II bertujuan untuk mengetahui tingkat kemampuan peserta didik dalam menulis biografi setelah 
dilakukan perbaikan dalam kegiatan belajar mengajar peserta didik yang didasarkan pada refleksi I. Pada setiap siklus dilakukan empat tahap. Empat tahap ini adalah tahap perencanaan, tindakan, pengamatan, dan refleksi.

Subjek dalam penelitian keterampilan menulis biografi adalah peserta didik kelas X SMA Negeri 9 Malang. Adapun sumber data yang digunakan adalah kelas X IPA 2 SMA Negeri 9 Malang. Dalam pengumpulan data penelitian, penulis menggunakan teknik tes dan teknik nontes. Teknik pengumpulan data merupakan langkah paling utama dalam penelitian karena tujuan utama dari penelitian adalah memperoleh data yang memenuhi standar data yang ditetapkan (Sugiyono, 2015, hal 308). Teknik tes digunakan untuk mendapatkan skor yang dihasilkan oleh peserta didik dalam menulis biografi dengan menggunakan model think talk write. Teknik nontes digunakan untuk mengetahui proses pembelajaran peserta didik.

Stainback (dalam Sugiyono, 2015, hal 335) menjelaskan teknik analisis data merupakan hal yang kritis dalam proses penelitian kualitatif dan kuantitaif. Analisis digunakan untuk memenuhi hubungan dan konsep dalam data, sehingga hipotesis dapat dikembangkan dan dievaluasi. Teknik analisis data yang digunakan dalam penelitian ini berupa teknik analisis data kuantitatif dan analisis data kualitatif. Teknik analisis data kuantitatif digunakan dengan cara menghitung data hasil penelitian yang diperoleh dari hasil tes peserta didik sebanyak empat kali, yaitu pada prasiklus, siklus I, dan siklus II. Nilai yang diperoleh peserta didik dianalisis untuk mengetahui perubahan hasil keterampilan peserta didik menulis poster pada setiap siklus. Teknik analisis data kualitatif digunakan untuk menganalisis data kualitatif yang diperoleh dari data nontes. Teknik kuantitatif yaitu teknik analisis data yang menggunakan metode statistik (Sugiyono, 2015, hal 333).Rumus yang digunakan untuk mengukur peningkatan keterampilan menulis biografi adalah sebagai berikut.

$$
N P=\frac{\left(\sum \mathrm{xi}\right)}{\mathrm{n}} \times 100 \%
$$

Keterangan :

$N P \quad$ : Nilai persentase tiap interval

$\sum x i \quad$ Jumlah frekuensi tiap interval

$n \quad$ : Jumlah nilai total maksimal

Untuk menghitung nilai rata- rata tiap aspek, maka digunakan rumus sebagai berikut.

$X=\frac{\left(\sum \mathrm{xi}\right)}{\mathrm{n}}$

(Sudjana 2015: 67)

Keterangan :

$\mathrm{X} \quad$ : Nilai rata- rata hasil tes

$\sum x i \quad$ : Jumlah bobot skor tiap aspek

n : Jumlah responden dalam satu kelas 
Analisis data yang disertai pengumpulan data dengan analisis secara statistik yang mengimplikasikan bahwa penelitian ini menggunakan metode penelitian kuantitatif. Data prestasi belajar peserta didik dapat diketahui dengan menghitung mean (rata-rata) dari daftar nilai peserta didik. Selanjutnya dari data penghitungan mean yang diperoleh mengacu pada tabel kategori pencapaian prestasi belajar. Teknik analisis data kuantitaf diperoleh dari hasil tes menulis biografi pada prasiklus, siklus I, dan siklus II. Keberhasilan penelitian dapat diketahui dari persentase peserta didik yang mendapat nilai memenuhi KKM yang diterapkan di SMA Negeri 9 Malang menjadi patokan nilai ketuntasan yaitu 78. Penelitian ini dapat dikatakan berhasil presentase nilai peserta didik apabila meningkat pada setiap siklus yang dilakukan.

Teknik kualitatif yaitu teknik analisis data yang diperoleh dari hasil wawancara, catatan lapangan, dan bahan-bahan lain sehingga dapat mudah dipahami dan temuannya dapat diinformasikan kepada orang lain (Sugiyono, 2010, hal 244). Dalam penelitian ini data kualitatif diperoleh dari instrumen nontes yang terdiri dari hasil observasi, wawancara, angket, dan dokumentasi. Skor hasil observasi dijumlah kemudian dikualitatifkan dan hasilnya digunakan untuk mengetahui perkembangan keterampilan peserta didik selama proses pembelajaran, sedangkan angket digunakan untuk mengetahui perubahan sikap peserta didik setelah proses pembelajaran menulis biografi dengan menggunakan model think talk write. Hasil wawancara digunakan untuk mengetahui perasaan, minat dan kesulitan analisis data kualitatif juga merupakan upaya yang dilakukan dengan melakukan pengamatan terhadap objek penelitian, berusaha berinteraksi dengan mereka, berupaya memahami kegiatan-kegiatan yang sedang terjadi atau berlangsung. Dalam teknis analisis data kualitatif ini, peneliti harus turun ke lapangan dengan waktu yang cukup lama.

\section{HASIL PENELITIAN DAN PEMBAHASAN}

Penelitian ini dilakukan dalam tiga tahap yaitu prasiklus, siklus I, dan siklus II. Dapat diketahui terjadi peningkatan proses pembelajaran menulis biografi, peningkatan keterampilan peserta didik dalam menulis biografi, dan perubahan perilaku peserta didik. Pembahasan hasil tersebut meliputi proses pembelajaran, hasil tes, dan nontes. Pada proses pembelajaran mengacu pada pelaksanaan pembelajaran berlangsung, pembahasan hasil tes mengacu pada perolehan nilai yang dicapai peserta didik dalam menulis biografi, sedangkan hasil nontes mengacu pada perolehan sikap dan motivasi peserta didik melalui observasi dan wawancara.

\section{Proses Pembelajaran Menulis Biografi melalui Model Think Talk Write pada Peserta Didik Kelas X IPA 2 SMA N 9 Malang}

Pada pelaksanaan proses pembelajaran menulis biografi, penelitian ini dilakukan sebanyak dua siklus dengan diawali prasiklus. Penelitian prasiklus dilakukan untuk mengetahui kondisi awal peserta didik dalam pembelajaran menulis biografi. Proses pembelajaran menulis biografi pada prasiklus peneliti tidak menggunakan model pembelajaran, sedangkan pada siklus I dan II peneliti menggunakan model pembelajaran Think Talk Write.

Proses pembelajaran menulis biografi melalui model think talk write pada siklus I dan siklus II dilakukan dua kali pertemuan pada setiap siklusnya. Tiap pertemuan selalu diawali dengan kegiatan pendahuluan dan apersepsi yaitu memancing peserta didik dengan pertanyaan-pertanyaan yang 
berkaitan dengan tokoh-tokoh internasional dan nasional agar siswa terlatih untuk berpikir. Kemudian peneliti menjelaskan kegiatan yang akan dilakukan siswa dan memberikan motivasi tentang pentingnya mempelajari menulis biografi dalam kehidupan sehari-hari.

Proses pembelajaran pada siklus I berbeda pada proses pembelajaran siklus II. Hal ini disebabkan oleh proses pembelajaran pada siklus II dilakukan perbaikan dari siklus I. Proses pembelajaran menulis biografi menggunakan model think talk write pada siklus I pertemuan pertama diisi dengan tanya jawab kesulitan siswa dalam menulis biografi pada siklus I. Pada kegiatan think untuk mencari informasi dari tokoh-tokoh nasional atau internasional yang menginspirasi. Pada saat kegitan talk proses tanya jawab mengenai hasil pencarian informasi dari tokoh-tokoh nasional atau internasionalpeserta didik sudah mampu aktif dibandingkan siklus I, begitu pula pada saat proses berlatih menulis biografi, siswa yang pada siklus I masih menulis hanya satu paragraf sudah dapat menulis sesuia dengan struktur biografi.

Berdasarkan proses pembelajaran menulis biografi pada siklus I dan II menggunakan model Think Talk Write, peserta didik merasa tertarik dan antusias. Peserta didik mampu berpikir mandiri dan bekerja sama dengan baik.

\section{Peningkatan Keterampilan Menulis Biografi melalui Model Think Talk Write pada Peserta Didik Kelas X IPA 2 SMA N 9 Malang}

Berdasarkan hasil tes menulis biografi melalui model think talk write diperoleh hasil bahwa nilai rata-rata peserta didik kelas X IPA 2 SMAN 9 Malang mengalami peningkatan.Peningkatan tersebut dapat diketahui dari pencapaian nilai rata-rata yang diperoleh peserta didik pada prasiklus, siklus I, dan siklus II. Dalam penelitian ini, terdapat 13 siswa belum tuntas KKM pada tahap prasiklus, 4 siswa belum tuntas KKM pada tahap siklus I, dan semua siswa sudah tuntas KKM pada tahap siklus II. Nilai rata-rata pada prasiklus dari 73,4 menjadi 79,7 pada siklus I, sehingga mengalami peningkatan sebesar Dari siklus I dengan nilai rata-rata 79,7 menjadi 88,6 pada siklus II, sehingga mengalami peningkatan sebesar 10,9\%. Dengan demikian, maka setiap siklus terjadi peningkatan yang dapat menjadikan peserta didik dapat menulis biografi dengan baik.

Pembahasan hasil penelitian dapat diketahui dari hasil prasiklus, siklus I, siklus II. Pembahasan hasil tes berpedoman pada pemerolehan skor yang dicapai peserta didik dalam tes pemahaman menulis biografi. Aspek-aspek penilaian terdiri atas lima aspek yaitu (1)struktur teks biografi, (2) unsur biografi, (3) kaidah kebahasaan biografi, (4) keefektifan kalimat, dan (5) ejaan dan tanda baca. Dari kelima aspek tersebut diakumulasikan menjadi satu untuk mendapatkan hasil tes menulis biografipada prasiklus, siklus I, dan siklus II. Perbandingan hasil penilaian dari empat aspek tersebut dapat dilihat dari tabel dan grafik di bawah ini. 
Tabel 1. Peningkatan Hasil Keterampilan Biografi Prasiklus, Siklus I, dan Siklus II

\begin{tabular}{lllll}
\hline \multirow{2}{*}{ No } & Aspek & \multicolumn{3}{c}{ Rata- rata } \\
\cline { 3 - 5 } & & Prasiklus & Siklus I & Siklus II \\
\hline 1 & Struktur teks biografi & 17,25 & 18,74 & 19,63 \\
\hline 2 & Unsur teks biografi & 16,43 & 17,58 & 19,46 \\
\hline 3 & $\begin{array}{l}\text { Kaidah kebahasaan } \\
\text { biografi }\end{array}$ & 14,6 & 15,74 & 17,37 \\
\hline 4 & Keefektifan kalimat & 14,37 & 15,76 & 18,33 \\
\hline 5 & Ejaan dan tanda baca & 10,75 & 11,88 & 13,81 \\
\hline Nilai & Akhir & $\mathbf{7 3 , 4}$ & $\mathbf{7 9 , 7}$ & $\mathbf{8 8 , 6}$ \\
\hline
\end{tabular}

Berdasarkan Tabel 1 tersebut hasil tes keterampilan menulis biografi dari prasiklus, siklus I, dan siklus II dapat dijelaskan bahwa keterampilan menulis biografi pada setiap aspek mengalami peningkatan. Hasil tes menulis biografi pada prasiklus diperoleh nilai rata-rata 73,4 nilai tersebut diperoleh dari beberapa aspek penilaian. Pada aspek struktur teks biografi memperoleh nilai ratarata 17,25, aspek unsur teks biografi 16,43, aspek kaidah kebahasaan 14,6, aspek keefektifan kalimat 14,37, dan aspek ejaan dan tanda baca 10,75.

Hasil tes menulis biografi pada siklus I diperoleh nilai rata- rata 79,7 dengan kategori baik pada rentang nilai 74-84, nilai tersebut diperoleh dari beberapa aspek nilai. Pada aspek struktur teks biografi memperoleh nilai rata-rata 18,74 , aspek unsur teks biografi memperoleh nilai rata-rata 17,58, aspek kaidah kebahasaan biografi 15,74, aspek keefektifan kalimat memperoleh nilai 15,76, dan aspek ejaan dan tanda baca 11,88. Dengan demikian, diketahui peningkatan dari prasiklus ke siklus I mencapai 8.6\%.

Hasil tes menulis biografi pada siklus II diperoleh nilai rata-rata 88,6 dengan kategori sangat baik pada rentang nilai 85-100, nilai tersebut diperoleh dari beberapa aspek penilaian. Pada aspek struktur teks biografi memperoleh nilai rata-rata 19,63, aspek unsur teks biografi memperoleh nilai rata-rata 19,46, aspek kaidah kebahasaan biografi memperoleh nilai rata-rata 17,37, aspek keefektifan kalimat memperoleh nilai rata-rata 18,33, dan aspek ejaan dan tanda baca memperoleh nilai rata-rata 13,81. Dengan demikian, diketahui peningkatan dari siklus I ke siklus II mencapai $11,1 \%$.

Peningkatan nilai rata-rata tiap aspek pada prasiklus, siklus I, dan siklus II dalam penggunaan model Think Talk Write dapat meningkatkan keterampilan menulis biografi peserta didik kelas X IPA 2 SMAN 9 Malang. Dengan demikian, dapat disimpulkan bahwa melalui model Think Talk Write dapat menjadikan peserta didik tertarik terhadap pembelajaran dan memotivasi peserta didik dalam pembelajaran menulis khususnya keterampilan menulis biografi. 


\section{Perubahan Perilaku Peserta Didik Kelas X IPA 2 SMAN 9 Malang setelah Mengikuti Pembelajaran Menulis Biografi dengan Model Think Talk Write}

Penelitian yang dilakukan oleh peneliti tidak hanya keterampilan menulis biografi, tetapi juga meneliti perubahan tingkah laku peserta didik setelah mengikuti pembelajaran menulis biografi menggunakan model Think Talk Write. Perilaku peserta didik sebelumnya cenderung kurang peduli dengan pembelajaran yang dilakukan. Hal ini dapat diubah ke arah positif setelah melakukan siklus I dan II. Hal ini dapat diketahui dari hasil nontes siklus I dan II yang meliputi observasi dan wawancara.

Pada observasi perubahan perilaku peserta didik dapat diketahui dari hasil observasi setelah dilaksanakannya siklus I dan II yang menggunakan model think talk write. Hasil observasi ini berdasarkan perubahan sikap dan motivasi peserta didik. Hasil observasi sikap belajar peserta didik pada siklus I dan siklus II dapat diketahui dari perubahan perilaku sikap peserta didik secara keseluruhan mengalami peningkatan. Peningkatan tersebut dapat diketahui dengan perubahan sikap peserta didik saat mengikuti pembelajaran. Pada siklus I peserta didik kurang antusias dan memperhatikan penjelasan dari guru, namun setelah diterapkan model pembelajaran think talk write peserta didik dapat bersungguh-sungguh dalam mendengarkan penjelasan guru.

Adapun peserta didik yang selama pembelajaran kurang aktif dalam memerhatikan materi yang dijelaskan oleh guru, setelah menggunakan model pembelajaran think talk write peserta didik mengalami perubahan sikap menjadi lebih aktif mencatat materi dari guru. Terdapat pula peserta didik yang kurang aktif bertanya kepada guru mengenai hal- hal yang belum dipahami dan kurang jelas, setelah mendapat pembelajaran think talk write, peserta didik menjadi lebih aktif dan percaya diri dalam bertanya. Hal ini karena dalam model think talk write, fase think peserta didik dituntut untuk berpikir kritis.

Selain observasi perubahan sikap peserta didik, terdapat juga motivasi peserta didik dalam pembelajaran. Observasi motivasi peserta didik digunakan untuk mengetahui perubahan perilaku motivasi belajar peserta didik menjadi lebih baik. Hasil observasi terlihat motivasi belajar peserta didik meningkat. Hal ini dapat dilihat dari ketertarikan peserta didik dalam pembelajaran menulis biografi yang sebelumnya merasa kurang tertarik, mulai mengalami perubahan. Perubahan ini terjadi setelah diterapkan model pembelajaran think talk write pada pembelajaran.

Sebelum menggunakan model pembelajaran, peserta didik kurang senang dan bersemangat dalam mengikuti pembelajaran menulis biografi, setelah diterapkan model pembelajaran think talk write peserta didik mengalami perubahan yaitu lebih bersemangat dan senang dalam mengikuti pembelajaran. Perubahan sikap yang lain adalah keberanian peserta didik untuk mempresentasikan hasil pekerjaannya. Peserta didik yang biasanya masih kurang aktif dalam menjelaskan saat presentasi, menjadi bersemangat setelah diterapkannya model pembelajaran think talk write dalam menulis biografi.

Berdasarkan uraian tersebut dapat disimpulkan bahwa secara keseluruhan peserta didik mampu menunjukkan perubahan sikap dan motivasi belajar yang baik. Tingkah peserta didik yang negatif sebelum diterapkan model pembelajaran mengalami perubahan ke arah positif setelah direrapkan model think talk write pada pembelajaran menulis biografi. 
Wawancara digunakan untuk mengetahui perubahan perilaku dan motivasi peserta didik setelah pembelajaran. Dari hasil wawancara sikap peserta didik pada siklus I dan II, dapat diketahui tanggapan peserta didik terhadap pembelajaran menulis biografi mengalami perubahan ke arah yang lebih baik. Data wawancara didapat dari tiga peserta didik yang memiliki nilai tertinggi, sedang, dan rendah. Hal ini dapat dilakukan untuk mengetahui sikap belajar peserta didik menulis biografi menggunakan model think talk write.

Berdasarkan wawancara yang dilakukan oleh tiga orang peserta didik, masing- masing memiliki jawaban yang berbeda. Peserta didik yang mendapatkan nilai tertinggi merasa tertarik dengan pembelajaran yang dilakukan, sedangkan peserta didik yang mendapat nilai sedang menjawab sedikit tertarik, dan peserta didik yang mendapatkan nilai kurang menjawab tidak tertarik dengan pembelajaran menulis biografi.

Selain wawancara sikap terdapat wawancara motivasi belajar peserta didik. Wawancara ini dilakukan pada siklus I dan II. Hal ini dilakukan untuk mengetahui motivasi peserta didik terhadap pembelajaran menulis biografi menggunakan model think talk write. Dari hasil wawancara siklus I dan II dapat diketahui bahwa ketiga peserta didik pada dasarnya senang dan tertarik mengikuti pembelajaran menulis biografi menggunakan model think talk write. Model ini mempermudah peserta didik dalam menulis biografi .

\section{PENUTUP}

Simpulan dari hasil penelitian tentang keterampilan menulis biografi melalui model think talk write pada peserta didik kelas X IPA 2 SMA Negeri 9 Malang adalah sebagai berikut. (1) Proses pembelajaran menulis biografi melalui model think talk write pada siklus II diketahui mengalami perubahan ke arah positif dibanding siklus I. Perubahan tersebut dapat diketahui dari catatan observasi yang peneliti tulis setelah melakukan proses pembelajaran menulis biografi melalui model think talk write; (2) Terdapat peningkatan keterampilan menulis peserta didik kelas X IPA 2 SMA Negeri 9 Malang setelah dilakukan tindakan penelitian menulis biografi menggunakan model think talk write. Peningkatan keterampilan menulis biografi tersebut dapat diketahui dari hasil prasiklus, siklus I, dan siklus II. Nilai rata-rata tes menulis biografi pada tahap prasiklus sebesar 73,4 yang masuk dalam kategori cukup. Pada siklus I nilai rata-ratanya mencapai 79,7 dengan kategori baik Pada siklus II, nilai rata-rata mengalami peningkatan 8,9 dari siklus I menjadi 88 dengan kategori sangat baik. dan (3) Terdapat perubahan perilaku peserta didik kelas X IPA 2 SMA Negeri 9 Malangsetelah mengikuti pembelajaran menulis biografi melalui model think talk writemengalami perubahan perilaku jujur, tanggung jawab, kreatif, komunikatif, dan mandiri. Perubahan tingkah laku peserta didik ini dapat dibuktikan dengan data nontes. Data nontes tersebut antara lain berupa lembar observasi perilaku, lembar wawancara, jurnal guru dan jurnal peserta didik, serta dokumentasi foto. Berdasarkan hasil data nontes pada siklus I, perilaku peserta didik pada tiap langkah pembelajaran sudah meningkat meskipun tidak signifikan. Pada siklus II, perilaku meningkat pada tiap langkah pembelajaran secara signifikan ke arah positif.

Saran dari hasil penelitian menulis biografi melalui model think talk write pada peserta didik kelas X IPA 2 SMA Negeri 9 Malang sebagai berikut. (1) Bagi guru mata pelajaran bahasa dan sastra Indonesia hendaknya melalui model think talk write dalam kegiatan pembelajaran menulis 
biografi. Berdasarkan hasil penelitian yang telah dilakukan, peserta didik yang terlibat dalam pembelajaran menulis biografi melalui model think talk write meningkat keterampilannya serta mampu menumbuhkan perilaku berkarakter yaitu perilaku perilaku jujur, tanggung jawab, kreatif, komunikatif, dan mandiri (2) Bagi peserta didik, peserta didik hendaknya berlatih menulis terutama berlatih menulis biografi dengan memperhatikan kelengkapan struktur dan unsur kebahasaan yang tepat, kaidah kebahasaan, keefektifan kalimat, dan ketepatan ejaan yang dapat mengatasi kesulitan belajar dalam pembelajaran menulis biografi. (3) Bagi kepala sekolah sebagai pemegang tampuk tertinggi dalam organisasai suatu sekolah diharapkan dapat memiliki kemampuan manajerial yang baik dalam melaksanakan fungsi-fungsi manajemen pada setiap komponen. Untuk mendukung proses pembelajaran, perlu adanya integrasi secara internal antara unsur pengajar, kepala sekolah serta seluruh warga sekolah untuk mengembangkan sarana dan prasarana yang memadai di sekolah. (4) Bagi para peneliti hendaknya melakukan penelitian lanjutan dari penelitian ini dengan menggunakan metode lain yang lebih variatif dan kreatif sehingga dapat memperkaya khazanah ilmu dan meningkatkan kualitas pendidikan di Indonesia.

\section{DAFTAR PUSTAKA}

Anisah, Sulfah. (2010). "Peningkatan Keterampilan Menulis Karangan Narasi dengan Mengubah Teks Wawancara melalui Model Think Talk Write Pada Siswa kelas VII A SMP Negeri 2 Cepiring". Skripsi. Semarang: Unnes.

Ansari. (2003). Ebook browse. http://ebookbrowse.com/modelpembelajaran-menulis-denganteknik-think (diakses pada tanggal 16 Februari 2019).

Arikunto, Suharsimi, et al. (2008). Penelitian Tindakan Kelas. Jakarta: PT Bumi Aksara.

Harahap, Syahrin. (2014). Metodeologi Studi Tokoh dan Penulisan Biografi. Jakarta: Prenadamedia Group.

Kusmaryono, Imam, Dyana Wijayanti, dan Evi Chamalah. (2016). Pembelajaran Mikro. Semarang; Unissula Press.

Rosidi, Imron. (2009). Menulis Siapa Takut? http://books.google.co.id/books/about/Menulis Siapa_Takut (diakses pada tanggal 8 Februari 2019)

Sugiyono. (2015). Metode Penelitian dan Pengembangan Research and Development. Bandung: Alfabeta.

Sukirno. (2016). Belajar Cepat Menulis Kreatif Berbasis Kuantum. Yogyakarta: Pustaka Pelajar.

Suparno dan Yunus. (2008). Keterampilan Menulis. Jakarta: Universitas Terbuka. 